\title{
PERLINDUNGAN HAK ATAS KEKAYAAN INTELEKTUAL BATIK TRADISIONAL PAOMAN \\ DALAM MENINGKATKAN EKONOMI MASYARAKAT INDRAMAYU
}

\author{
Ujang Suratno \\ Universitas Wiralodra, Indramayu \\ Email : faujura_1804@yahoo.com
}

\begin{abstract}
Indonesia has some varieties of ethnic groups that are rich in diversity of intellectual property, there are so many products produced by society. The society creations especially created by the community are assorted, one of them is Paoman Batik. Thre are two kinds of Paoman Batik, those are contemporary and traditional, which is distinguished by its motives, processes, creators. The Paoman Traditional Batik is well-known to the public than contemporary. This research has supported the creators or copyright holders to get higher benefits, both the benefits of moral and economic rights. The main problem is, first, is the current intellectual property rights regime able to provide the foundation for the protection of Paoman Traditional Batik? Second, is the UNESCO's determination that stated if batik is a world heritage, non-object from Indonesia, can be used as the foundation to charge the economic rights of Paoman Traditional Batik? Third, is it possible for Traditional Batik, including Paoman Traditional Batik, to be carried out through other regimes, in addition to the intellectual property regime? Fourth, how is the effect of Paoman Traditional Batik Registered at the Directorate General of Intellectual Property of Indonesia on the Progress of Indramayu society?
\end{abstract}

The research method used is descriptive specification, by using juridical empirical approach, which focus on secondary research consisting of legal materials, both primary, secondary and tertiary. However it is supported by primary data generated from field research through indepth interview and survey techniques. The analysis used is descriptive analysis.

The results of the study show that intellectual property rights that is copyright cannot be made as the foundation of protection against the creation of society that have traditional and communal motives, including the Paoman Tradsional Batik. The establishment of Batik by UNESCO as a non-object world heritage from Indonesia has increased the moral rights of Indonesia, but it also cannot be established as the foundation for restoring economic rights when there is a misappropriation. Another alternative to intellectual property is through the Sui Generis regime, which specifically addresses the protection of community rights, including intellectual property rights.

\section{Keywords: Intellectual Property Right (IPR), Society, and Protection.}

\section{PENDAHULUAN}

Indonesia memiliki berbagai macam suku bangsa yang sangat kaya akan keragaman kekayaan intelektual, berbagai produk banyak dihasilkan masyarakat. ${ }^{1}$ Di berbagai daerah di

${ }^{1}$ Dalam konteks global untuk menjelaskan sistem pengetahuan masyarakat tradisional di negara-negara berkembang digunakan beberapa istilah seperti "indigenous knowledge, traditional knowledge, local knowledge". Sementara di Indonesia sering digunakan istilah "sistem pengetahuan masyarakat asli, sistem pengetahuan masyarakat adat, dan sistem pengetahuan masyarakat lokal". Dalam tulisan ini menggunakan istilah hak milik intelektual produk masyarakat Lokal. 
wilayah Indonesia banyak berbagai produk hasil karya intelektual masyarakat lokal yang menunjukan kekhasan dari produk wilayah tertentu. Di Jawa Barat terdapat berbagai karya masyarakat yang bersifat kolektif yang khas dibatasi wilayah geografis, antara lain seni Batik Trusmi Cirebon, Batik Pamoman Indramayu, dan Batik Garutan.

Batik Paoman merupakan salah satu hasil seni batik masyarakat Paoman Kabupaten Indramayu Jawa Barat. Paoman merupakan salah satu kelurahan yang berada di wilayah Kecamatan Indramayu Kabupaten Indramayu. Sejak dahulu masyarakat Kelurahan Paoman, dahulu namanya Desa Paoman, banyak memiliki keahlian membuat seni batik dan kegiatan kerajinan batik, sehingga menjadi menjadi sentra batik. Saat ini sentra batik sudah menyebar pada beberapa kecamatan yaitu kecamatan Indramayu meliputi Kelurahan Paoman dan Desa Pabean, kecamatan DSindang meliputi Desa Penganjang, Babadan, dan Desa Terusan.

Batik Paoman termasuk dalam kategori batik tradisional, pertama, corak hias dan motif batik tersebut sudah sejak lama ada yang diturunkan dari generasi ke generasi, sehingga tidak diketahui lagi nama pertama pembuat motif-motif tersebut; kedua, teknik pembuatan, dan bahan atau media yang digunakan; ketiga, batik Paoman memiliki motif yang khas yang berbeda dengan batik-batik lainnya seperti Batik Trusmi dan Batik Garutan; keempat, saat ini tidak ada perubahan motif batik dan corak hias sehingga ciri khas yang ada sejak dahulu tetap tidak berubah.

Sebagai sebuah hasil karya, cipta, dan rasa, batik merupakan kekayaan intelektual seseorang, sehingga seseorang yang yang telah menciptakan seni batik dengan motif dan ragam hias yang khas memiliki hak atas hasil kekayaan intelektualnya tersebut. Terdapat dua ha katas kekayaan intelektual yang dimiliki pencipta, yaitu hak moral dan hak ekonomi. Hak moral merupakan konsekuensi dari pemikiran bahwa setiap hasil karya orang lain harus diakui dan diberi penghargaan, walaupun tidak mengandung nilai ekonomis, atau dengan kata lain hak moral adalah pengakuan manusia terhadap hasil karya orang lain yang sifatnya non ekonomi. ${ }^{2}$ Sedangkan hak ekonomi adalah hak yang dimiliki pencipta/pendesain/penemu untuk memperoleh keuntungan ekonomi atas ciptaannya dengan cara memperoleh pembayaran dari pihak yang mengggunakan ciptaan/temuan/ desainnya berdasarkan kontrak. ${ }^{3}$ Dengan demikian hak moral merupakan suatu hak yang melindungi kepentingan pribadi atau reputasi pencipta yang melekat pada pribadi pencipta dan tidak dapat dipisahkan dari penciptanya, sedangkan hak ekonomi adalah segala hak yang dapat mendatangkan

\footnotetext{
${ }^{2}$ Eddy Damian, Hukum Hak Cipta, PT. Alumni, Bandung, 2009, hlm. 8.

${ }^{3}$ Abdulkadir Muhammad, Op. Cit, hlm. 114
} 
keuntungan ekonomi kepada pemiliknya, seperti memperoleh pembayaran dari pihak yang mengunakan, dan lain-lain. ${ }^{4}$

Kedua hak tersebut sangat penting baik bagi individu, masyarakat, maupun Negara. Hak moralitas mengandung pengakuan terhadap hasil cipta seseorang sehingga orang yang bersangkutan memiliki reputasi. Sedang hak ekonomi menurut Peter Groves pada dasarnya merupakan hak yang dimiliki oleh pencipta/pendesain/penemu atau pemegang hak untuk mengeksploitasi ciptaan/temuannya dan memperoleh keuntungan ekonomi dari eksploitas ciptaan/temuannya tersebut. ${ }^{5}$ Berdasarkan hak ekonomi yang dipunyai, memungkinkan seseorang pencipta, atau penemu, mengeksploitasi suatu karya cipta sedemikian rupa untuk memperoleh keuntungan-keuntungan ekonomi. Penjelasan Umum UU No. 19 Tahun 2002 menyebutkan bahwa hak ekonomi adalah hak untuk mendapatkan manfaat ekonomi atas ciptaan serta produk hak terkait. Dengan demikian kedua hak tersebut dapat menumbuhkan dorongan motivasi yang kuat bagi pencipta untuk lebih giat berkarya, karena selain reputasi pengakuan atas ciptaannya, juga memiliki nilai ekonomi yang dapat bermanfaat buat kehidupannya, bahkan secara tidak langsung dapat meningkatkan pendapatan masyarakat atau pendapatan negara dari hasil-hasil karya ciptaan anak bangsanya.

Mengingat pentingnya kedua hak tersebut baik bagi reputasi dan peningkatan ekonomi individu, masyarakat ataupun Negara, maka kedua hak tersebut perlu dilindungi secara memadai. Di samping itu sebagaimana dikemukakan Eddy Damian perlunya pengelolaan suatu ciptaan, temuan, atau desain dilindungi hukum, karena suatu ciptaan, temuan, atau desain jika tidak dikelola secara tertib berdasarkan seperangkat kaidah hukum, dapat menimbulkan sengketa antara pemilik hak cipta dengan pengelola (pemegang) hak cipta atau pihak lain yang melanggarnya. Untuk pengaturannya diperlukan seperangkat ketentuan hukum yang efektif dari segala kemungkinan pelanggaran oleh mereka yang tidak berhak atas hak cipta yang dimiliki seseorang. ${ }^{6}$

Namun permasalahannya adalah, pertama bahwa batik-batik tradisional, seperti halnya batik tradisonal Paoman tidak ditemukan penciptanya atau non name, bahkan telah dianggap sebagai hasil karya masyarakat. Kedua, bahwa batik tradisional tidak terdokumentasikan dan termasuk bentuk pengetahuan yang tidak terdokumentasikan. Apakah kondisi ini dapat dilindungi oleh Undang-Undang No. 28 tahun 2014 tentang Hak Cipta?

\footnotetext{
${ }^{4}$ Abdulkadir Muhammad, Hukum Harta Kekayaan, Citra Adytia Bakti, Bandung, 1994, hlm. 114-115.

5 Peter Groves, Intellectual Property With Compettion Law and Praktices, Cavendish Publishing Limited, London, 1999, hlm. 1.

${ }^{6}$ Eddy Damian, Loc cit. 
Saat ini umumnya sistem perlindungan hak milik intelektual tidak menjangkau karya intelektual yang tidak terdokumentasikan seperti karya intelektual masyarakat dan bentukbentuk pengetahuan yang tidak sistematis meskipun bersifat dinamis dan terus menerus mengalami evolusi, seperti halnya hasil (produk) intelektual masyarakat di Indonesia. Agreement on Trade Related Aspects of Intellectual Property Rights (TRIPs) dalam General Agreement on Tariff and Trade (GATT) WTO tidak secara jelas mengatur tentang hak milik intelektual hasil krativitas masyarakat.

Sementara itu berkembangnya industrialisasi ke seluruh penjuru dunia, telah menimbulkan benturan kepentingan antara pengusaha penganut sistem hak milik intelektual yang mengutamakan komersialisasi kreativitas intelektual dengan pemilik karya intektual tradisional. Di satu sisi, kalangan pengusaha industri maju tidak menginginkan adanya perlindungan terhadap kekayaan intelektual produk masyarakat yang dinilainya sudah menjadi public domein, dan mereka beranggapan bahwa proses modernisasi masyarakat lokal dan/atau tradisional merupakan kompensasi yang memadai bagi pemanfaatan karya intelektual tradisional. Di sisi lain sebagai karya intelektual tanpa diskriminasi hak kekayaan intelektual produk masyarakat harus tetap dilindungi, sebagaimana TRIPs WTO melindungi hak milik intelektual yang berorientasi pada pandangan negara-negara maju. ${ }^{7}$ Hal lain yang banyak menimbulkan konflik dalam pelaksanaan hak atas kekayaan intelektual masyarakat, seperti halnya batik tradisional Paoman.

Berbagai perbedaan pandangan tersebut, pada akhirnya berpengaruh pada perlindungan atas hak milik intelektual produk masyarakat lokal, seperti terjadinya berbagai kegiatan komersialisasi dan penjiplakan desain tradisional di industri fashion, pengakuan terhadap produk-produk batik Indonesia, kesenian sebagai produk warisan budaya Indonesia, dan pagelaran musik dengan unsur tradisional yang seringkali mengabaikan kompensasi bagi pemilik pengetahuan tradisional. ${ }^{8}$ Komersialisasi dan penjiplakan, serta pengakuan (claim) tersebut terus berlangsung tanpa adanya perlindungan, seperti pada kasus Batik Khas Padang diakui sebagai hasil produk bangsa Malaysia. Kondisi ini akan merugikan bangsa Indonesia, bukan hanya pada persoalan ekonomi semata, tetapi juga pada jati diri atau reputasi bangsa Indonesia. ${ }^{9}$

${ }^{7}$ Kusnaka Adimihardja, "Atas Kepemilikan Intelektual : Melindungi Hak Komunal Adat dan Lokal", Pikiran Rakyat, 5 Mei 2001, hlm. 9.

${ }^{8}$ Noegroho Amien Soetiarto, "Hak Atas Kekayaan Intelektual dan Kekayaan Intelektual Tradisional dalam Konteks Otonomi Daerah", dalam Mimbar Hukum, Edisi No. : 34/II/2000, hlm. 72.

${ }^{9}$ Hasil Teleconference on Intellectual Property Rights yang diselenggarakan oleh ELIPS kerjasama dengan Fakultas Hukum UNPAD dengan Setale University California, seperti dikutip R. Achmad Gusman Catur Siswandi et al., Pengaturan Mengenai hak Kekayaan Intelektual dan Perlindungan Pengetahuan Tradisional (Traditional Knowledge) Dalam Bidang Pengobatan di Indonesia, Hasil Penelitian, Fakultas Hukum UNPAD, 2001, hlm. 13. 
Terjadinya misappropriation ${ }^{10}$ tersebut juga disebabkan karena sebagian besar masyarakat Indonesia, terutama masyarakat lokal kurang menyadari akan pentingnya perlindungan terhadap hasil karya intelektual yang dimilikinya, ${ }^{11}$ mereka sering kali membiarkan hasil ciptaannya dijiplak orang, bahkan merasa bangga apabila hasil ciptaannya banyak dipakai orang. ${ }^{12}$ Selain hal tersebut, lemahnya perlindungan terhadap hak milik intelektual produk masyarakat lokal karena perlindungan pengetahuan tradisional lazimnya dilakukan dengan mekanisme hukum adat dan kebiasaan yang secara informal serta melalui berbagai aturan, hak, dan kewajiban yang hanya berlaku di dalam komunitas itu sendiri. Kelemahan lainnya adalah kebiasaan yang berdasarkan pengalaman dan selalu berulang-ulang diturunkan dari suatu generasi ke generasi berikutnya dilakukan secara oral/tidak tertulis. Hukum kebiasaan ini diawasi dan ditegakan oleh para sesepuh dan para tokoh agama di komunitasnya. ${ }^{13}$

Adanya pertentangan antara kepentingan pengusaha yang beroreintasi pada trade global dan pemahaman tentang kepemilikan intelektual pada masyarakat negara-negara maju dengan pemahaman hak milik intelektual pada masyarakat belum dapat terpecahkan. Namun mulai disadari bahwa hak milik intelektual produk masyarakat harus dilindungi, mengingat selain memiliki hak moral, juga memiliki hak ekonomi, yang secara non diskriminatif harus dilindungi. ${ }^{14}$

Belum adanya perlindungan hukum terhadap hak kekayaan intelektual produk masyarakat, termasuk batik tradisonal Paoman berdampak pada perekonomian masyarakat daerah sendiri yang sangat tergantung pada sumber daya alam sebagai kekayaan masyarakat daerah. Masyarakat Indramayu yang pada umumnya mendiami wilayah pedesaan kehidupannya sangat bergantung pada kekayaan alam yang memberikan hak secara melekat pada kekayaan intelektual mereka. Dengan demikian setiap hasil seni batik Paoman pada

${ }^{10}$ Misappropriation diartikan sebagai penggunaan oleh pihak asing dengan mengabaikan hak-hak masyarakat atas pengetahuan tradisional dan sumber daya hayati yang terkait, menjadi milik masyarakat yang bersangkutan. Pemahaman ini didasarkan pada pengertian misappropriation yang dalam Blacks Law Dictionary dari pengertian teknis terungkap dalam berbagai pertemuan internasional menyangkut perlindungan tradisional knowledge, genetic resources dan folklore. Black's Law Dictionary (1990 : 998) mengartikan misappropriation sebagai "the unauthorized, improper or unlawful use of funds or property for purpose other than that for which intented".

${ }^{11}$ Yusril Ihza Mahendra, Keynote Speakers in WIPO Asia-Pasific Regional Symposium on Intellectual Property Rights, Traditional Knowledge and Related Issues, Yogyakarta, Indonesia, Oktober 17 to 19, 2001

12 Rajendra Baskara, salah seorang pengusaha Batik Roro Jonggrang Yogyakarta, seperti dikutip Ugrasena Pranidhana dalam Penelitiannya mengenai "Hak Cipta Tradisional, Suatau Kajian Hak Cipta Menurut Pandangan Tradisional" dalam Jurnal Penelitian Fakultas Hukum Iniversitas Indonesia Volume 1, No.2, Januari 2000, hlm. 6.

${ }^{13}$ Yusril Ihza Mahendra, op cit., hlm. 5.

${ }^{14}$ Article 8, ILO Convention 169; Article 12 and 13, Draf United Nations Declaration on the Rights of Indigenous Peoples (1994); and Principle 4, 'Principles and Guidelines for the Protection of the Heritage of Indigenous People', United Nations Sub-Commission on Prevention of Discrimination and Protection of Minorities. 
dasarnya merupakan hasil buah pikiran masyarakat Paoman baik yang berasal dari individu maupun kolektif. Oleh karena itu tidak adanya perlindungan terhadap hak kekayaan intelektual Batik Paoman dapat mengurangi hak ekonomi masyarakat terhadap produkproduk yang telah dihasilkannya. ${ }^{15}$

Saat ini UNESCO salah satu lembaga PBB yang membidangi masalah-masalah kebudayaan telah menetapkan Batik sebagai warisan Dunia yang berasal dari Indoensia. UNESCO mengakui batik sebagai warisan dunia karena memenuhi kriteria antara lain kaya symbol dan makna filosofis kehidupan masyarakat Indonesia. Teknik, simbolisme, dan budaya terkait batik dianggap melekat dengan kebudayaan Indonesia, bahkan UNESCO menilai masyarakat Indonesia memaknai batik dari prosesi kelahiran sampai kematian. ${ }^{16}$

Pengakuan UNESCO PBB terhadap Batik termasuk batik Paoman, secara hak moral telah memperoleh kemajuan, karena reputasi bangsa Indonesia pada masyarakat dunia semakin meningkat. Namun permasalahannnya bagaimana dengan hak ekonomi bangsa Indonesia, apakah secara otomatis diperoleh bilamana Negara-negara lain menjiplak atau menggunakannya ? Jika juga secara peraturan perundang-undangan yang berkaitan dengan perlindungan terhadap hak cipta belum dapat melindungi batik tradisional Paoman, bagaimana sebaiknya pengaturan dilakukan?

\section{METODE}

Penelitian ini menggunakan metode pendekatan Yuridis Emperik, yakni penelitian yang menitikberatkan pembahasan pada data-data sekunder berupa bahan-bahan hukum, baik primer, sekunder maupun tersier, yang didukung data primer. Pendekatan yuridis digunakan untuk membahas ketentuan perundang-undangan mengenai Hak Cipta yang terkait dengan perlindungan terhadap Batik Paoman Indrmayu.

Spesifikasi penelitian ini adalah deskriptif analitis, yaitu penelitian yang bertujuan menggambarkan mengenai fakta-fakta disertai analisis yang akurat mengenai peraturan perundang-undangan yang berlaku baik nasional maupun internasional dihubungkan dengan teori-teori hukum dan praktek yang berkaitan dengan hak cipta, serta dampaknya terhadap perekonomian masyarakat di daerah.

15 Hilman Hadikusuma, Hukum Perekonomian Adat Indonesia, Citra Aditya Bakti, Bandung, 2001, hlm. 1-10. Kusnaka Adimihardja, "Mendayagunakan Kearifan Tradisi Dalam Pertanian Yang Berwawasan Lingkungan dan Berkelanjutan", dalam Kusanaka Adimihardja dkk, Petani Merajut Tradisi Era Globalisasi, Humaniora Utama Press, Bandung, 1999, hlm. 4.

${ }^{16}$ UNESCO menetapkan batik sebagai Warisan Kemanusiaan untuk Budaya Lisan dan Nonbendawi (Masterpieces of the Oral and the Intangible Heritage of Humanity) pada tanggal 2 Oktober 2009. hhtps://nasional.kompas.com. 
Teknik pengumpulan data dilakukan melalui Penelitian kepustakaan dan Penelitian di lapangan. Penelitian kepustakaan dilakukan untuk memperoleh bahan-bahan hukum baik primer, sekunder, maupun tersier. ${ }^{17}$ Bahan hukum primer adalah bahan-bahan yang berasal dari peraturan perundang-undangan, konvensi internasional, perjanjian internasional yang relevan. Dalam penelitian ini akan difokuskan pada pengkajian peraturan perundangundangan dibidang hak Cipta, yaitu UU No. 28 Tahun 2014 tentang Hak Cipta. Bahan hukum sekunder yakni terdiri dari doktrin-doktrin, pendapat para ahli yang dapat terlihat dalam buku-buku hukum dan makalah-makalah yang ditulis oleh para ahli, karangan berbagai panitia pembentukan hukum, hasil penelitian hukum, RUU dan lain-lain yang dapat memberikan penjelasan mengenai bahan hukum primer. Di samping itu dikaji pula bahan hukum tersier, yakni berupa pendapat-pendapat atau opini masyarakat yang ada di dalam majalah-majalah dan surat kabar, kamus, ensiklospedi, yang dapat memberikan petujuk maupun penjelasan terhadap bahan hukum primer maupun sekunder. ${ }^{18}$ Sedangkan Penelitian Lapangan Penelitian lapangan dimaksudkan untuk mendukung analisis bahanbahan hukum primer, sekunder, dan tersier. Teknik yang digunakan adalah melakukan wawancara terhadap informan, yaitu orang yang mengetahui mengenai Batik Paoman dan Hak Cipta. Penelitian lapangan dimaksudkan untuk mendukung analisis bahan-bahan hukum primer, sekunder, dan tersier. Teknik yang digunakan adalah melakukan wawancara terhadap informan, yaitu orang yang mengetahui mengenai Batik Paoman dan Hak Cipta.

Teknis Analisis data yang digunakan dalam penelitian ini adalah deskriptif kualitatif normatif, yakni pemaparan dan penggambaran peraturan perundang-undangan secara kualitatif, yang didukung oleh data-data primer yang diperoleh dari studi lapangan. Pada teknik analisis ini, pertama-tama dilakukan analisis yuridis pada berbagai peraturan baik nasional maupun internasional. Kemudian kedua, hasil-hasil studi lapangan yakni data primer dikumpulkan, dikategorikan, di klasifikasikan kemudian direduksikan kedalam atauranaturan yang telah dianalsis tersebut. Hasil reduksi bahan hukum dengan data primer dilakukan analisis dan disimpulkan.

\section{PEMBAHASAN}

\subsection{Pendekatan Teori Perlindungan Hak Atas Kekayaan Intelektual Batik Paoman}

${ }^{17}$ Sunaryati Hartono, Penelitian Hukum di Indonesia Pada Akhir Abad ke-20, Alumni, Bandung, 1994, hlm. 134

${ }^{18}$ Soerjono Soekanto dan Sri Mamuji, Penelitian Hukum Normatif, Grafindo Persada, Jakarta, 1995. 
Teori utama perlindungan Hak atas Kekayaan Intelektual Masyarakat adalah Teori Hak Milik Kolektif, sebagaimana digambarkan Working Group on Indigenous Population (WGIP). ${ }^{19}$ Draft principles prepared at a strategy meeting attended by 90 indigenous representatives and submitted to the WGIP at its 1985 session left little doubt as to the central aspiration on indigenous participant :

"All indigenous peoples have the right of self-determination, by virtue of which they have the right of whatever degree of autonomy the choose. This includes the right to freely determine their political status, the right to freely pursue their own economic, social, religion and cultural development and determine their own membership and/or citizenship whitout external inference."

Semua masyarakat memiliki hak untuk mengembangkan dirinya, untuk melaksanakan hak yang mereka miliki secara otonom. Termasuk hak untuk menetapkan status politik, bebas dari tekanan ekonomi, sosial, agama, dan pengembangan kebudayaan, serta hak-hak mereka sebagai anggota warga Negara tanpa pengaruh dari siapapaun.

Selanjutnya draft WGIP mengakui hak-hak masyarakat asli/lokal untuk menentukan dirinya sendiri, seperti persamaan hak, bebas dari diskriminasi, berpartisipasi dalam kehidupan negara, dan bangsa. Pasal 3 menyatakan : "Indigenous people have the right of self-determination. By virtue of this right, they freely determine their political status and freely puruse their economic, social, and cultural development."

Selanjutnya Pasal 4 menyatakan bahwa masyarakat asli/lokal memiliki hak untuk untuk memelihara dan mengembangkan karakteristik dan sistem hukumnya, serta partisipasi dalam kehidupan bangsanya. Pasal khususnya ditujukan pada masyarakat asli sebagai bagian masyarakat lokal. Pada masyarakat Indonesia yang telah merdeka dari penjajahan, dimana terdiri dari berbagai macam komunitas suku bangsa yang memiliki karakteristik dan sistem hukumnya memiliki kebebasan untuk mengembangkannya termasuk mengimplementasikannya dalam kehidupan sehari-hari. Di samping itu masyarakat asli memiliki hak kolektif untuk hidup bebas, damai dan aman seperti orang-orang lain, dan jaminan penuh dari pemusnahan secara teratur suatu golongan bangsa, termasuk pemusnahan/penghilangan anak-anak.

Pasal 7 sampai dengan Pasal 11 secara tegas memerinci hak-hak individu dan kolektif sebagai berikut :

19 Kelompok Kerja untuk Masyarakat Adat (Working Group on Indigenous Population/WGIP) dibentuk oleh Dewan Ekonomi dan Sosial PBB. WGIP merupakan simpul pelaksanaan (focal point) dalam system PBB untuk mempromosikan hak-hak masyarakat adat, terdiri dari 5 ahli independen yang juga merupakan anggota sub komisi untuk promosi perlindungan hak asasi manusia. 
“(1) not to be subjected to ethnocide and cultural genocide (including prevention of and redress for dispossession, imposed assimilation and integration); and

(2) to maintain and develop distinct identities and characteristics (including the right of self-identification)."

(3) to belong to an Indigenous community or nation.

(4) Not to be forcibly removed from their lands or territories, and

(5) To special protection and surety in periods of armed conflict.

Pasal 12-14 menyatakan hak-hak yang berhubungan dengan identitas budaya, agama, dan bahasa Masayarakat Asli, termasuk- hak-hak ini, yaitu :

“(1) to practice and revitalize cultural traditional and customs (including the right torestitution of cultural, intellectual, religious and spiritual property);

(2) to practice and develop spiritual and religious traditions (including the rights to religious and cultural sites and to the repatriation of human remains);

(3) to the revitalisation, use and transmission of histories, languages, oral traditions, writing system and literature (including the right to designate name for communities, place ad persons)"

Selanjutnya Pasal 29 Draft WGIP PBB menyatatakan : “Indigenous people are entitled to recognition of the ownership, control and protection of their intellectual and cultural property and to special measures to control, develop and protect their sciences, technologies and cultural manifestations."

Tampak pasal tersebut menjamin untuk memajukan dan melindungi kepemilikan, melakukan kontrol dan perlindungan terhadap hak kekayaan intelektual (intellectual property right), dan kepemilikan budaya, dan secara khusus melakukan pengawasan, pengembangan dan perlindungan terhadap pengetahuan, teknologi, dan mewujudkan kebudayaannya.

Dalam melakukan pengembangan, masyarakat memiliki hak untuk memperoleh kebebasan dan informasi dari berbagai kegiatan yang dilakukan terhadap masyarakat, tanah, wilayah, dan sumber daya lainnya, dan secara khusus didalam pengembangan, pemanfaatan, dan eksploitasi sumber daya mineral dan air. Hal ini sebagaimana ditegaskan Pasal 30 Draft WGIP :

"Affirms the right of Indigenous peoples to require that states obtain their free and informed consent prior to the approval of projects affecting their lands, territories and other resources, particularly in connection with the development, utilization or exploitation of mineral and water resources."

Bentuk lain dari hak masyakat lokal disebutkan dalam Pasal 32 sampai dengan Pasal 36 sebagai berikut :

(1) to determine their citizenship in accordance with their custioms and traditions; 
(2) to develop and maintain their institutional structures and juridical customs, proceadures and practices;

(3) to determine the responsibilities of individuals to their communities;

(4) to maintain and develop relations and cooperation with other peoples across borders; and

(5) to the recognition and enforcement of treaties, agreements and other constructive arrangements concluded with States or their successons."

Perserikatan Bangsa-Bangsa secara tegas melindungi hak-hak asasi manusia bukan hanya ditujukan pada hak-hak manusia secara individu, tetapi juga pada hak asasi manusia secara kolektif, seperti hak sosial, ekonomi, dan budaya, termasuk didalamnya hak milik intelektual yang dimiliki secara kolektif oleh kelompok-kelompok masyarakat yang secara spesifik memiliki kebudayaan dan kebiasaannya sendiri.

Pada kepemilikan produk masyarakat yang bersifat kolektif komunal, maka hal terpenting yang harus diperhatikan bahwa setiap generasi harus menjaga dan menyimpan produk masyarakat tersebut secara berhati-hati secara turun-temurun. Karena sifatnya tersebut produk masyarakat lokal belum memiliki perlindungan berupa kepemilikan berdasarkan sistem hukum yang tepat. Padahal perlindungan bagi produk masyarakat akam memberikan beberapa keuntungan termasuk :

a. Menghapus (atau mengurangi) rasa ketidakadilan;

b. Mencegah penggunaan pengetahuan dalam cara yang merugikan pemiliknya;

c. Pengakuan luar biasa terhadap nilai pengetahuan tradisional dan menghormati siapapun yang telah memeliharanya.

d. Menjaga sumberdaya secara optimal untuk memunculkan standar kehidupan dan tingkat pembangunan, khususnya dinegara berkembang;

e. Pemanfaatan pengetahuan tradisional yang lebih berguna di seluruh dunia;

f. Memelihara gaya hidup tradisional;

g. Melindungi atau memelihara lingkungan.

\subsection{Batik Paoman Sebagai Khas Batik Tradisional Indramayu}

Beberapa pandangan yang berkaitan dengan batik sebagai produk hasil pemikiran manusia, dikemukakan beberapa ahli. Hazmuri mendefinisikan batik adalah lukisan atau gambar pada mori yang dibuat dengan menggunakan alat yang bernama canting. Orang melukis atau menggambar atau melukis pada mori memakai canting disebut membatik. ${ }^{20} \mathrm{Hal}$

${ }^{20}$ Hazmuri, Batik Klasik, Jambatan, Jakarta, 1981, hlm. 6. 
sama dikemukakan Ismunandar bahwa batik adalah lukisan di atas kain putih dengan memakai canting, dimana lukisan itu menggunakan lilin yang kemudian diberi warna. ${ }^{21}$

Definisi tersebut hanya mencakup batik yang dibuat oleh tangan dengan memakai canting, yang sering disebut Batik Tulis, sedangkan pada saat ini terdapat juga batik yang pembuatannya dicap, atau disebut pula Batik Cap. Oleh karena itu Kusnaka Adimihardja, dkk. mendefinisikan batik adalah suatu karya seni rupa pada kain yang dibuat dengan teknik pewarnaan rintang dengan menggunakan lilin batik sebagai perintang warna. Difinisi ini mencakup batik tulis dan batik cap. ${ }^{22}$

Batik pada dasarnya merupakan hasil kreativitas pemikiran manusia Indonesia yang khas. Batik merupakan seni kerajinan khas Indonesia, yang dihasilkan melalui proses pembuatan motif-motif batik di atas bahan dasar dengan memakai lilin batik, kemudian diwarnai dengan warna khusus untuk batik. ${ }^{23}$ Bahan tekstil hasil pewarnaan tersebut memiliki corak-corak khas motif batik Indonesia, secara pencapan rintang dengan menggunakan lilin batik sebagai zat perintang. ${ }^{24}$

Menurut Nian Soerianata Djoemena, hasil lukisan ini yang kemudian antara lain disebut dengan nama ragam hias, umumnya sangat dipengaruhi dan erat hubungannya dengan faktor-faktor :

(1) Letak geografis daerah pembuat batik yang bersangkutan.

(2) Sifat dan tata penghidupan daerah yang bersangkutan.

(3) Kepercayaan dan adat istiadat yang ada di daerah yang bersangkutan.

(4) Keadaan alam sekitarnya, termasuk flora dan fauna.

(5) Adanya kontak atau hubungan antar daerah pembatikan. ${ }^{25}$

Sebagi hasil karya pemikiran manusia, pembuatan batik memiliki proses penciptaan dengan memakai beberapa peralatan untuk mewujudkan ciptaan terebut. Beberapa peralatan digunakan untuk menciptakan batik, antara lain kain mori, canting, lilin, dan pewarna.

${ }^{21}$ R.M. Ismunadar, Tehnik dan Mutu Batik Tradisional Mancanegara, Dahara Prize, Semarang, 1985, hlm. 7.

${ }^{22}$ Kusnaka Adimihardja, dkk. Deskripsi Pengetahuan dan Teknologi Lokal Jawa Barat, Laporan Kegitan Inventarisasi dan Dokumentasi, Kerjasama UPT INRIK UNPAD dengan P2KT PUD-PKM BPP Teknologi, Bandung, 2003, hlm. 57. Bdgk Hamzuri, op cit, hlm.6. menyatakan, dalam perkembangan selanjutnya dipergunakan alat-alat lain yang lebih baik untuk mempercepat proses pengerjaan, misalnya dengan cap. Demikian pula proses batik menjadi kain batik, oleh karena itu "kerja mencap inipun menghasilkan motif seperti batik, yang sebenarnya bukan batik lagi. Cap akan menghasilkan kain dengan motif seperti batik, karena hasilnya bukan batik lagi, maka lebih tepat diberi nama "kain motif batik".

${ }^{23}$ Wailah Abu Sudja, Proses Pembuatan dan Pewarnaan Batik di Indonesia, Karya Nusantara, Bandung, 1979, hlm. 1

${ }^{24}$ Ditjen Industri Tekstil Departemen Perindustrian, Batik Keris, Pengalaman Eksportir Produsen Dalam Memasarkan Tekstil Khususnya di Luar Negeri, Jakarta, 1996, hlm 3

${ }^{25}$ Rahmaniar Soerianata Djoemena, Ungkapan Sehelai Batik : Its Mystery and Meaning, Djambatan, Jakarta, 1986, hlm. 1-2. 
Salah satu hasil intelektual masyarakat yang memiliki ciri khas adalah Batik Paoman. Batik Paoman adalah jenis batik yang diusahakan oleh masyarakat di Kabupaten Indramayu. Desa Paoman merupakan derah penghasil batik yang utama selain Desa Penganjang, Desa Peben Udik di Kecamatan Indramayu dan Desa Babadan serta Desa Tarusan di Kecamatan Sindang. Batik yang berasal dari Desa Pamoan sering disebut dengan Batik Paoman. ${ }^{26}$

Berdasarkan cara pembuatannya, hampir seluruh produksi Batik Paoman menunjukan sebagai ciri-ciri batik klasik dan tergolong sebagai batik tradisional yaitu suatu jenis karya batik yang dihasilkan secara turun-temurun, tumbuh dan berkembang dari kebiasaan masyarakat dari satu generasi ke generasi selanjutnya.

Batik Paoman tergolong batik beraliran pesisir, selain batik Cirebon dan Batik Pekalongan. Batik Indramayu ini mempunyai ciri khas tersendiri. Secara keseluruhan, motif Batik Indramayu tidak seberani motif batik Cirebon (terutama Batik Kraton), melainkan lebih berupa pembawaan yang hidup tetapi penuh ketenangan, yang kadang-kadang melonjak menjadi riang gembira. Warna-warna yang digemari adalah biru dengan motifnya yang bergaris pinggir warna biru tua atau warna lain dan merah mengkudu. Kadang-kadang tempat yang telah diberi lilin diisi dengan titik kecil dengan menggunakan alat complongan. Hanya sedikit pola diagonal yang diproduksi di Indramayu, mereka lebih menyukai desain yang bebas, hampir menyerupai lukisan. ${ }^{27}$

Motif batik Paoman pada umumnya tampak ada perbedaan dengan motif batik daerah lain, baik dalam bentuk gambar ornamen maupun dalam penggunaan warnanya. Motif Batik Paoman termasuk termasuk batik proletar. ${ }^{28}$ Dikatakan proletar karena motif Batik Paoman menggambarkan tentang keindahan alam, lingkungan yang tumbuh dan dijumpai dikalangan para petani dan nelayan setempat. Motif batik Paoman tergolong berani dan biasanya menggambil secara utuh burung, berbagai macam bunga dan tumbuh-tumbuhan (flora). Di samping itu motif batik Indramayu sangat dipengaruhi oleh kebudayaan yang datang dari luar dan berbagai unsur, antara lain lingkungan, kepercayaan dan adat istiadat masyarakat setempat. Motif gambar simbolik, ornamennya seperti abstrak tidak ada tetek gendek

${ }^{26}$ Kelurahan Pamoan termasuk kedalam wilayah Indramanyu, Jawa Barat. Jarak dari Desa Pamoan ke Kecamatan adalah 1,1 km, dari Ibu Kora Kabupaten di Indramayu berjarak 1,8 km, sedangkan dari ibukota propinsi berjarak $210 \mathrm{~km}$. Keadaan topograpi tanahnya merupakan dataran dengan produktivitas sedang. Luas wilayah Pamoan adalah 204.757 hektar. Sebelah Utara berbatasan dengan Kelurahan Karang Song, sebelah Selatan berbatasan dengan Kelurahan Margadadi, sebelah Barat berbatasan dengan Kelurahan Tahu, dan sebelah Timur berbatasan dengan Kelurahan Singajaya..

${ }^{27}$ Rahmaniar Soerianata Djoemena, op. cit, hlm. 40.

${ }^{28}$ Ibid, hlm. 41 
pengaruh batik Cirebon. Berbentuk seperti lukisan pelet atau hiasan dinding permadani kuno dari Turki. Sepintas bias dikategorikan pesisiran tetapi hanya sepintas dalam soal warna. Ciri yang paling menonjol pada dasar titik atau complongan. Dewasa ini hampir seluruh corak batik yang ada di Indramayu merupakan corak-corak klasik, hanya sebagian corak masa kini.

Pada saat ini tercatat 140 motif $\mathrm{klasik}^{28}$, antara lain : Motif Kembang Suket, Kembang Pete, Lasem Urang, Manuk Bengkuk, Lockan, Kereta Kencana, Merak Berunding, Manuk Drawes, Merak Ngibing, Pacar Cina, Perang Teja, Pentil Kusta, Sawat Pentil Kusta, Obar Abir, Sawat Biskuit, Rama, Rajeg Wesi, Puyong, Sejurig, Sawat Penganten, Sawat Riwog, Sawat Riweh, Srikit, Sisik, Sekar Niem, Sarempang Kandang, Teluki, Sungging Manuk Tetingkring, Swastika, Kembang Kapas, Kembang Kol, Kembang Betah, Kapal Kandas, Kembang Gunda, Kawung, Jae Sarempeng, Jati Rombeng, Iwak Etong, Ikat Petek, Ganggeng, Gorda, Dan Liris, Srintil, Teratai, Tiga Negeri, banji Tapak, Ayam Alas, Bokong Semar, Banji, dan Cendrawasih. ${ }^{29}$ Motif-motif klasik ini memiliki ciri khas, karakter, dan latar belakang sejarah, serta nilai-nilai yang terkandung didalamnya.

Sebagian besar batik Paoman mempunyai ciri tarikan canting besar untuk pertemuan garis lengkung dan lurus sangat kaku tidak di ikut isen-isen yang rumit, polanya menuju primitif. Dasar cemplongan yang di tonjolkan. Corak motifnya sangat terbatas. Warna yang dibuat sangat kuat dan redup tidak mengenal warna pokok warna batik Dermayon tidak terlalu banyak yaitu biru tua, hitam, merah tua, coklat kekuning-kuningan dan coklat kemerah-merahan. Warna coklat diperoleh dari buah mengkudu dan mahoni, batik dermayon umumnya berwarna latar putih, tapi bukan putih bersih. Hal ini akibat pelunturan dari warna utama. Sehingga batik tersebut mempunyai dua warna. Misalnya biru tua dengan dasar biru muda, atau coklat tua dengan dasar coklat muda dan sebagainya

\subsection{Perlindungan Batik Paoman Melaui Regim Hak Cipta}

Perlindungan hak cipta atas karya seni batik, sama halnya dengan perlindungan atas program komputer, dimulai sejak terjadinya penyempurnaan Undang-Undang No. 6 tahun 1982 menjadi Undang-Undang No. 7 Tahun 1987, kemudian diganti dengan Undang-Undang No. 19 tahun 2002 tentang Hak Cipta, serta selanjutnya diganti dengan Undang-Undnag No. 28 tahun 2014 tentang Hak Cipta. Hal ini terjadi karena dipacu oleh perkembangan teknologi informasi serta dalam rangka memberikan perlindungan pada karya tradisional, dengan latar

\footnotetext{
${ }^{28}$ Kantor Dinas Perdagangan dan Perindustrian Kabupaten Indaramayu, 2018.

${ }^{29}$ Keputusan Direktorat Jenderal Hak Cipta, Desain Industri, Desain Tata Letak Sirkut Terpadu, dan Rahasia Dagang, tanggal 15 Desember 2003.
} 
belakang itulah pada akhirnya karya program komputer dan batik digolongkan sebagai karya cipta yang dilindungi oleh Undang-Undang.

Undang-Undang No. 28 Tahun 2014 tentang Hak Cipta sebagai pengganti UndangUndang No. 19 tahun 2002. Pasal 40 ayat (1) huruf j menyebutkan karya seni batik atau seni motif lain termasuk karya seni yang dilindungi. Seni batik yang memperoleh perlindungan hukum adalah batik yang dibuat secara konvensional yang merupakan bentuk ciptaan tersendiri, karya-karya seperti itu memperoleh perlindungan karena mempunyai nilai seni, baik pada ciptaan motif atau gambar maupun komposisi warnanya.

Berkaitan dengan masalah penciptaan motif, para pencipta motif lebih dikenal dengan istilah Tukang Reng-reng. Di desa sentra industri kerajinan batik Kabupaten Indramayu Paoman umumnya menciptakan motif tidak secara murni dari hasil inspirasi dan imajinasinya sendiri, akan tetapi kebanyakan dari mereka memodifikasikan motif-motif yang telah ada, yang notabene merupakan motif tradisional, karena batik tradisional memilki ornament dan isen-isen yang berjumlah cukup banyak, sehingga untuk menciptakan sebuah motif batik para pencipta hanya merangkaikan atau memadukan ornament dan isen-isen yang telah ada. Sebagai contoh, apabila kita menjumpai suatu nama motif batik Lereng Kembang, maka hal ini berarti bahwa didalam motif tersebut terkandung adanya suatu ornament yang berbentuk Lereng dan ornament lainnya berbentuk Kembang.

Ciri batik tradisional dapat dengan mudah kita temui ketika kita melihat-lihat kain, baik dalam bentuk sarung, kemeja, taplak meja, hiasan dinding, dan lain-lain, kemudian kita mempunyai penilaian bahwa "itu batik". Berarti sudah dapat dipastikan bahwa kain tersebut merupakan batik tradisional. Cara pandang yang sederhana dalam menilai sebuah kain termasuk kategori tradisional atau bukan sebagaimana dikemukakan diatas, disebabkan karena batik tradisional memilki corak tertentu yang telah mengakar dan dikenal oleh orang banyak. Menurut keterangan Kepala Bagian Pengembangan Batik dari Balai Besar Pengembangan dan Penelitian Industri Kerajinan dan Batik (suatu lembaga resmi milik pemerintah dibawah naungan Departemen Perindustrian). Batik tradisional merupakan suatu kesatuan batik pada sehelai kain yang telah baku.

Berdasarkan pemahaman Hak Cipta di atas, maka ketentuan yang ada kaitannya dengan Batik Tradisional Paoman Indramayu, yakni ketentuan Pasal 38 ayat (1) UndangUndang No. 28 Tahun 2014 tentang Hak Cipta, yang menyatakan "bahwa hak cipta atas ekspresi budaya tradisonal dipegang oleh Negara". Selanjutnya Pasal 39 ayat (1) UndangUndang tersebut menyebutkan "bahwa dalam hal Ciptaan tidak diketahui Penciptanya dan 
Ciptaan tersebut belum dilakukan pengumuman Hak Cipta atas Ciptaan tersebut dipegang oleh Negara untuk kepentingan Pencipta”.

Pada tahun 2003 Pemerintah Kabupaten Indramayu telah mendaftarakan 80 motif Klasik Batik Paoman ke Direktorat Jenderal Hak Cipta, Desain Industri, Desain Tata Latak Sirkuit Terpadu, dan Rahasia Dagang dari 140 motif Batik Paoman. ${ }^{30}$ Kedelapan puluh motif yang terdaftar antara lain : Motif Kembang Suket, Kembang Pete, Lasem Urang, Manuk Bengkuk, Lockan, Kereta Kencana, Merak Berunding, Manuk Drawes, Merak Ngibing, Pacar Cina, Perang Teja, Pentil Kusta, Sawat Pentil Kusta, Obar Abir, Sawat Biskuit, Rama, Rajeg Wesi, Puyong, Sejurig, Sawat Penganten, Sawat Riwog, Sawat Riweh, Srikit, Sisik, Sekar Niem, Sarempang Kandang, Teluki, Sungging Manuk Tetingkring, Swastika, Kembang Kapas, Kembang Kol, Kembang Betah, Kapal Kandas, Kembang Gunda, Kawung, Jae Sarempeng, Jati Rombeng, Iwak Etong, Ikat Petek, Ganggeng, Gorda, Dan Liris, Srintil, Teratai, Tiga Negeri, banji Tapak, Ayam Alas, Bokong Semar, Banji, dan Cendrawasih.

Melalui proses kajian sejak 15 Desember 2003, motif-motof batik Paoman tersebut dinyatakan telah terdaftar di Direktorat Jenderal Hak Cipta, Desain Industri, Desain Tata Latak Sirkuit Terpadu, dan Rahasia Dagang- sekarang Direktorat Jenderal Hak Kekayaan Intelektual Kementerian Hukum dan HAM RI. Didalam pertimbangannnya bahwa motifmotif Batik Paoman yang diajukan termasuk karya seni yang dilindungi menurut Pasal 12 ayat (1) huruf i Undang-Undang Hak Cipta No. 19 Tahun 2002 tentang Hak Cipta bahwa batik yang dibuat secara konvensional yang merupakan bentuk ciptaan tersendiri, karya-karya seperti itu memperoleh perlindungan karena mempunyai nilai seni, baik pada ciptaan motif atau gambar maupun komposisi warnanya. Disamakan dengan pengertian seni batik adalah karya tradisional lainnya yang merupakan kekayaan bangsa Indonesia yang terdapat diberbagai daerah, seperti seni songket, ikat, dan lain-lain yang dewasa ini terus dikembangkan.

Gambaran berkaitan dengan motif tradisional dan pengkuan atas pendaftaran Batik Tradisional Paoman, dapat terlihat pada pertimbangan atas pendaftaran motif-motif Batik Paoman sebagai berikut : ${ }^{31}$

a. Motif Kembang Kapas. Nama kembang kapas diambil dari tanaman kembang kapas. Sesuai dengan namanya maka wujud corak ini kembang (bunga) kapas. Tanaman ini pada jaman dahulu merupakan pembatas antara daerah Derma Ayu dengan Babadan

\footnotetext{
${ }^{30}$ Kantor Dinas Perdagangan dan Perindustrian Kabupaten Indaramayu, 2018.

${ }^{31}$ Keputusan Direktorat Jenderal Hak Cipta, Desain Industri, Desain Tata Letak Sirkut Terpadu, dan Rahasia Dagang, tanggal 15 Desember 2003.
} 
yang kemudian oleh para orng tua dituangkan pada batik. Motif ini terdaftar pada Dirjen Hak Cipta, Desain Industri, Desain Tata Letak Sirkuit Terpadu, dan Rahasia Dagang No. 023954, tanggal 26 September 2003.

b. Motif Ganggeng. Corak ini menggambarkan tanaman ganggeng yang banyak tumbuh di pesawahan Indramayu Utara. Motif ganggeng ini menunjukan betapa motif dermayon memiliki karater proletar, karena keseluruhan motif secara jelas menggambarkan tumbuhan-tumbuhan. Warna batik biru gelap sebagai ciri keseluruhan motif Dermayon. Motif ini terdaftar pada No. 023964 , Juni 2003.

c. Motif Urang Ayu. Corak ini kemungkinan ada hubungannya dengan Ki Urang, seorang pahlawan Indramayu ketika melawan Mataram. Urang bisa berarti 'Udang' atau 'Orang'. Pada hakikatnya urang melukiskan makna, figur dalam ikonografi Hindu, sosok separuh manusia, yang diasosiasikan dengan Dewa Wisnu, dengan lambang sufit urang, atau 'jepit udang'. Supit urang juga merupakan istilah militer untuk siasat perang dimana musuh diserang dari samping dengan kekuatan menyerang ada ditengah. ${ }^{32}$. Corak ini tampaknya juga permaksud untuk menggambarkan bahwa para nelayan daerah Indramayu banyak menghasilkan udang yang bagus. Motif ini terdaftar pada bulan September 2003 No. 023927.

d. Sawat Riweh, pada corak ini terlihat kaligrafi arab yang tersembunyi, kemungkinan corak ini dahulu digunakan untuk panji-panji. Dewasa ini dalam pembuatan corak sawet riwe seringkali tampa kalighrafi., dan riwe diartikan rumbai-rumbai, didalam corak ini terlihat adanya pengaruh dari Jawa Tengah. Kebijaksanaan untuk memukimkan penduduk Jawa Tengah ke daratan Indramayu pada abad ke-17 dan sesudahnya, telah jelas berpengaruh pada pola lambang mataram yang khas, seperti sayap-sayap garuda pada jenis-jenis lar, mirong, dan sawat sebagaimana terlihat pada corak sawat riwe. Meskipun demikian, karena tidak terikat ketentuan-ketentuan Keraton Jawa, bentuk dan besarnya sama sekali berlainan. Warna biru gelap merupakan ciri khas Batik Dermayonan. Terdaftar pada bulan September 2003 No. 023946.

e. Sawat Penganten, corak ini berupa gambar mahkota yang melambangkan penguasa tinggi. Meskipun namanya Sawat Penganten tidak berarti bahwa kain dengan corak ini diperuntukan bagi penganten. Istilah penganten untuk menunjuk kepada sepasang mahkota. Sekalipun warna agak cerah, namun garis-garis hitam menunjukan karakter

${ }^{32}$ Yayasan Mitra Budaya Indonesia, Batik Tradisiona1, Jakarta, 1982 hlm. 136 
batik Dermayon yang cenderung warna gelap. Motif ini terdaftar pada tanggal 26 September 2003 No. 023944.

f. Manuk Drawes. Motif ini menggambarkan bahwa pada jaman dahulu banyak burung bengkuk. Pintu Raja dalam termasuk dalam Desain geometri yang masih sangat populer di daerah Indramayu, meskipun haya tinggal sedikit saja. Bentuknya memperlihatkan bahwa desain itu pernah merupakan lambang-lambang antariksa, tetapi nama diberi menurut penggunaan lambang ini yang praktis dan fungsional. Selain corak ini ada pula corak yang dinamakan mata angin dan pintu ratu. Corakcorak ini bentuknya menyerupai kompas. Motif Manuk Bengkuk juga termasuk motif yang sudah terdaftar.

Motif-motif tradisional ini kesemuanya telah terdaftar pada Dirjen Hak Cipta, Desain Industri, Tata Letak Sirkuit Terpadu, dan Rahasia Dagang- Saat ini namanya Direktorat Jenderal Kekayaan Intelektual Kementerian Hukum dan HAM RI, dengan pemegang Hak Cipta Pemerintah Daerah Kabupaten Indramayu, sedangkan Penciptanya Asosiasi Pengusaha Batik Indramayu. Ditetapkannya Pemegang Hak Cipta Pemerintah Daerah Indramayu merupakan implementasi dari ketentuan Pasal 10 ayat (1) Undang-Undang No. 19 tahun 2002 menyebutkan "bahwa dalam hal Ciptaan tidak diketahui Penciptanya dan Ciptaan tersebut belum dilakukan pengumuman Hak Cipta atas Ciptaan tersebut dipegang oleh Negara untuk kepentingan Pencipta”. Pemerintah Daerah merupakan representasi dari Negara di tingkat Kabupaten.

Berdasarkan pasal tersebut, maka Negara memegang Hak Cipta atas Batik Paoman . Negara merupakan subyek hukum publik, yang dalam pelaksanaannya terdapat beberapa subyek hukum publik di bawahnya, seperti provinsi atau Kabupaten/Kota. Dalam kasus Batik Paoman, maka selain Negara Republik Indonesia yang dapat memegang hak ciptanya, Pemerintah Kabupaten Indramayu adalah pemegang Hak Cipta Batik Paoman Indramayu.

Dengan dipegangnya Hak Cipta oleh Pemerintah Kabupaten Indramayu, maka Pemda kabupaten Indramayu memiliki hak Ekonomi, selain Hak Moral. Dengan demikian, orang yang bukan warga Negara Indonesia bila berkehendak ingin mengumumkan atau memperbanyak ciptaan Batik Tradisional Paoman harus terlebih dahulu mendapat izin dari Pemda Kabupaten Indramayu, khususnya instansi yang terkait dengan masalah ini (Pasal 10 ayat 3$)$.

Dalam penjelasan Pasal 10 UU No. 19 Tahun 2002, disebutkan bahwa ketentuan ini dimaksudkan untuk melindungi foklor dan hasil kebudayaan rakyat lainnya. Pemerintah dapat mencegah adanya monopoli atau komersialisasi serta tindakan yang merusak atau 
pemanfaatan komersial tanpa seizin Negara Republik Indonesia sebagai pemegang hak cipta. Disamping itu ketentuan ini dimaksudkan untuk menghindari tindakan pihak asing yang dapat merusak nilai kebudayaan tersebut.

Dengan ketentuan tersebut, berarti Negara dalam hal ini Pemda Indramayu dapat memberikan izin kepada pihak lain dan/atau warga Negara Asing untuk memperbanyak atau mengumumkan Batik Tradisional Paoman Indramayu, dengan memperoleh restitusi berupa hak-hak ekonomi maupun morak Batik Tradisional Paoman. Izin dapat berupa Lisensi, Waralaba, ataupun Francise. Hak izin juga sekaligus juga memberikan hak untuk menolak pihak lain atau pihak asing untuk menggunakan atau memperbanyak Ciptaan Batik Tradisional Paoman, bila dipandang akan merugikan Negara atau hasil kebudayaan Batik Tradisional.

Pada dasarnya Pasal 10 Ayat (2) dan Pasal 12 Ayat (1) huruf i UU No. 19 tahun 2002 tentang Hak Cipta dapat dijadikan dasar bagi perlindungan Hak Cipta atas Batik Tradisional paoman, namun terdapat beberapa kesukaran Batik Tradisional Paoman masuk kedalam Regim Hak Cipta, yaitu :

(1) Ciptaan harus dalam bentuk yang asli. Pada umumnya Batik Trusmi Cirebon sudah tidak lagi menampakan keaslian bentuk batik pada mulanya, sehingga yang ada adalah dalam bentuk derivatifnya. Hal ini disebabakan beberapa afaktor antara lain :

(a) Dilakukan dari generasi ke genarasi, sehingga yang asli tidak nampak lagi.

(b) Terdapat kebiasaan masyarakat jika ciptaannya ditiru orang sangat senang hati.

(2) Batas Waktu yang ditetapkan selama 50 tahun pada Hak Cipta, merupakan kendala utama dalam hak cipta Batik Tradisional, karena batik tersebut dibuat sudah berabadabad lamanya. Di samping itu lepas dari 50 tahun maka batik Tradisional Paoman menjadi milik public (public domain)"

Namun dilihat dari perspektif UU No. 28 tahun 2014, Batik Tradisional Paoman tidak termasuk merupakan karya seni yang dilindungi. Penjelasan Pasal 40 ayat (1) huruf j menyebutkan :

"Yang dimaksud dengan karja seni batik adalah motif batik kontemporer yang bersifat ivovatif, masa kini, dan bukan tradisional. Karya tersebut dilindungi karena mempunyai nilai seni. Baik dalam kaitannya dengan gambar, corak, maupun komposisi warna.

Yang dimaksud dengan karya seni motif lain adalah motif yang merupakan kekayaan bangsa Indonesia yang terdapat, seperti seni songket, motif tenun ikat, motif tapis, motif ulos, dan seni motif lain yang bernilai kontemporer, inovatif, dan terus dikembangkan." 
Berbeda dengan Pasal 12 ayat (1) UU No. 19 tahun 2002 yang dalam penejalasannya tidak menyebutkan harus kontemporer dan bukan tradisonal. Didalam UU No. 28 tahun 2014, Pasal 40 ayat (1) huruf $\mathrm{j}$ nampak disebutkan disebutkan bahwa yang dilindung bukan motif batik tradisional, seperti motif batik tradisional Paoman tetapi motif batik kontemporer yang bersifat ivovatif, masa kini. Selanjutnya motif lainnya yang dimaksud pada Pasal 40 ayat (1) huruf $\mathrm{j}$ tersebut juga bukan motif tradisional tetapi motif kontemporer.

Ditetapkannya Pemegang Hak Cipta Pemerintah Daerah Indramayu oleh Direktorat Jenderal Hak Kekayaan Intelektual yang didasarkan ketentuan Pasal 10 ayat (1) UndangUndang No. 19 tahun 2002, dilihat dari perspektif UU No. 28 tahun 2014, khususnya Pasal 38 ayat (1) dan Pasal 39 ayat (1), dimaksudkan bukan melindungi Batik sebagaimana disebutkan Pasal 40 ayat (1) huruf j. Didalam penjelasan Pasal 38 ayat (1) menyebutkan bahwa yang dimaksud dengan "ekspresi budaya tradisional mencakup salah satu atau kombinasi ekspresi sebagai berikut :

“a. Verbal tektual, baik lisan maupun tulisan yang berbentuk prosa maupun puisi, dalam berbagai tema dan kandungan isi pesan, yang dapat berupa karya sastra ataupun narasi infromatif,

b. Musik mencakup antara lain vocal, instrumental, atau kombinasi.

c. Gerak mencakup antara lain tarian;

d. Teater, mencakup antara lain, pertunjukan wayang dan sandiwara rakyat;

e. Seni rupa baik dalam bentuk dua dimensi maupun tiga dimensi yang terbuat dari berbagai macam bahan seperti kulit, kayau, bamboo, logam, batu, keramik, kertas, tekstil, dan lain-lain atau kombinasinya, dan

f. Upacara adat."

Sedangkan Penejalasan Pasal 39 ayat (1) Undang- Undang No. 28 Tahun 2014 menyebutkan : "Ketentuan ini dimksudkan untuk menegaskan status Hak Cipta dalam suatu karya yang penciptaannya tidak diketahui dan belum diteribtkan, misalnya dalam hal karya tulis yang belum diterbitkan dalam bentuk buku atau karya musik yang belum direkam". Nampak seolah-olah Pasal 39 ayat (1) ini melindungi setiap ciptaan yang belum diketahui Penciptanya dan belum diterbitkan termasuk Motif Batik Tradisional, namun didalam jajaran karya seni yang dilindungi baik berdasarkan Pasal 40 ayat (1) maupun Pasal 38 ayat(1) UU No. 28 tahun 2014 tidak ditemukan bahwa Motif Batik Tradisional seperti Motif Batik Paoman dapat dilindungi. Dengan demikian, maka Batik Tradisional Paoman Indramayu tidak dapat dilindungi berdasarkan Pasal 38 ayat (1), Pasal 39 ayat (1) dan Pasal 40 Ayat (1) huruf j UU No. 28 Tahun 2014 tentang Hak Cipta. 


\subsection{Perlindungan Motif Batik Tradisonal Paoman Melalui Pembentukan Undang- Undang Sui Generis}

Nampak bahwa perlindungan Batik Tradisional Paoman sulit dilakukan melalui regim Hak Kakayaan Intelektual berdasarkan Undang-Undang No. 28 tahun 2014 tentang Hak Cipta. Oleh karena itu alternatif lain perlindungan dilakukan melalui regim sui generis. Beberapa Negara mengusulkan sistem perlindungan sui generis sebagai alternatif untuk melindungi produk masyarakat, khususnya pengetahuan tradisional. ${ }^{33}$ Sistem ini telah diterapkan pula guna melindungi teknologi menyangkut varietas tanaman, ${ }^{34}$ sebagai alternatif perlindungan atas penemuan (invention) di bidang tersebut yang juga dapat dilindungi dengan paten.

Menurut Rebbeca Clement, kekayaan budaya sudah seharusnya dilindungi oleh Negara asal dari kekayaan budaya tersebut. Dalam Hukum Internasional telah diakui. ${ }^{35}$ Kekayaan budaya yang dimaksudkan Clements adalah dalam arti cultural property yang lebih mengacu kepada benda-benda (fisik) hasil kreativitas kebudayaan suku bangsa asli di suatu Negara. Namun demikian kiranya pendapat tersebut mengandung kebenaran pula bilamana diterapkan pada kekayaan budaya dalam arti ekspresi folklore ataupun pengetahuan tradisional lainnya. Keduanya merupakan hasil kreativitas kebudayaan. Dalam konteks ini Indonesia dapat mempertimbangkan sistem sui generis mengingat karakteristik masyarakat Indonesia yang sangat berbeda dengan masyarakat Barat. Karakteristik masyarakat Indonesia masih kuat diwarnai sistem kolektif atau komunal dan religious, sehingga perilaku masyarakatnya pun masih diresapi dan dituntun oleh sistem nilai tersebut. ${ }^{36}$ Dengan demikian menciptakan hukum yang berlandaskan sistem nilai yang berbeda hanya akan menimbulkan masalah dalam implementasinya.

Negara lain yang telah menerapkan Sui Generis adalah Filipina, melalui Republic Act No. 8371, sejak diundangkan tanggal 29 Oktober 1997, Filipina melindungi hak-hak masyarakat lokal, termasuk hak milik intelektualnya. Republic Act No. 8371 merupakan wujud penjabaran sekaligus perintah konsitusi Filipina (Philipina Constitution, 1987), yang sudah menetapkan memberikan perlindungan terhadap masyarakat asli (indigenous people). Sec 3 h. Republic Act No. 8371 menyebutkan :

"Indigenous Cultural Communities/Indigenous People-refer to a group of people or homogenous societies identified by self ascription and ascription by other, who have continuously lived as organized community on communally bounded and defined

\footnotetext{
${ }^{33}$ WIPO, Intellectual Property Needs, 2001.

${ }^{34}$ Indonesia telah mempunyai Undang-Undang tentang Perlindungan Varietas Tanaman, yaitu UU No. 29 tahun 2000 (LN Tahun 2000 No. 241.

${ }^{35}$ Rebecca Clement, "Misconception of Culture Native Peoples and Cultural Property Under Canadian Law”, Toronto Faculty of Law Review (Vo. 49 No. 1, 1991), hlm. 2

${ }^{36}$ Satjipto Rahardjo, Sisi-Sisi Lain dari Hukum di Indonesia, Buku Kompas, Jakarta, 2003, hlm. 96.
} 
territory, and who have, under clime of ownership since time immemorial, occupied, possessed and utilized such territories, sharing common bons of language, custom, traditions and other distinctive cultural traits, or who have, through resistence to political, social, and cultural inroads of colonization, non-indegenous religion, and culture, becames historically differentiated from the majority of Filipinos...."

Tampak dalam Republic Act No. 8371 melindungi hak-hak masyarakat yang sangat luas, meliputi hak kepemilikan, hak hidup, hak politik, hak sosial, hak budaya, hak bergama, dan lain-lain hak. Dengan demikian masyarakat lokal Filipina/masyarakat asli dilindungi dari perbuatan misappropriation. Didalam Republik Act No. 8371 ini pun diatur mengenai Free and Prior Informed Consent.

Substansi yang terpenting dari undang-undang sui generis adalah adanya pengakuan yang tegas bahwa masyarakat lokal adalah pemilik dari produk-produk lokal tersebut. Kiranya hukum adat atau hukum kebiasaan (customary law) dapat menjadi salah satu alternatif sumber atau bahan untuk merumuskan hak-hak masyarakat lokal tersebut di dalam undang-undang sui generis. ${ }^{37}$ Prinsip-prinsip dalam hukum adat yang dapat diakomodasi ke dalam undang-undang sui generis antara lain : Pertama, pengaturan di dalam undang-undang sui generis bersifat sederhana. Artinya, apa yang diatur di dalam undang-undang tersebut mudah dimengerti dan dipahami oleh masyarakat secara luas, dan pelaksanaannya pun tidak membutuhkan prosedur yang rumit sebagaimana halnya perundang-undangan Hak Milik Intelektual. Karakteristik ini sejalan dengan pola pikir masyarakat yang juga sederhana. Pola pikir sederhan itu antara lain tercermin dalam sistem hukum adat yang bersifat terang dan tunai. Hukum Adat tidak mengenal lembega hukum yang bersifat abstrak sebagaimana halnya lembaga hukum kekayaan intelektual. ${ }^{38}$

Kedua, undang-undang sui generis itu hendaknya tidak mengabaikan unsur-unsur yang berlandaskan norma agama. Hal ini sejalan dengan sistem hukum adat yang bersifat religius magis. Unsur ini menjadi faktor utama yang menyebabkan masyarakat tidak terlampau bersifat materialistik. Ukuran penghargaan tidak hanya sekedar bersifat material dalam bentuk imbalan ekonomis, sebagaimana reward dalam regim Hak Milik Intelektual. Penghargaan juga mencakup penghargaan terhadap sistem kepercayaan atau keyakinan bahwa pengetahuan adalah karunia Tuhan yang harus disyukuri dan diamalkan untuk kesejahteraan umat manusia.

Ketiga, undang-undang sui generis itu hendaknya tetap berlandaskan kepada sistem kemasyarakat yang sangat menghargai kebersamaan. Ini sejalan dengan sistem hukum adat

${ }^{37}$ Lihat Kembali pembahasan kasus Milpurru vs Indofurn (Pty) Ltd, dalam Cristine Haight Farley, "Protecting Foklore of Indigenous Peoples is Intellectual Property the Answer ?", Conecticut Law Review, (Fall, 1997, hlm 4-7, dikutip dari Agus Sardjono, op cit, hlm. 249. Dalam kasus ini penentuan mengenai siapa pemilik dari desain yang dipersengketakan dilakukan berdasarkan Hukum Adat.

${ }^{38}$ Agus Sardjono, Ibid, hlm. 251 
yang tidak individualistik. Dengan kata lain bahwa undang-undang sui generis hendaknya tidak berlandaskan pada prinsip atau paham individualisme sebagaimana regim hak milik intelektual. Mengadopsi sistem individualistik hanya akan berarti mengulangi kekeliruan rezim Hak Milik Intelektual yang telah terbukti kurang berhasil implementasinya.

Keempat, undang-undang sui generis itu harus mampu menjamin atau sekurangkurangnya memberikan kemungkinan yang besar agar pemanfaatan pengetahuan tradisional beserta praktek-praktek yang terkait dengannnya benar-benar-benar dapat memberikan kesejahteraan bagi masyarakat pada umumnya. Dalam hal ini undang-undang yang bersangkutan harus dapat memberikan kepastian bahwa masyarakat yang menjadi custodian dari pengetahuan yang bersangkutan benar-benar akan memperoleh manfaat dari pengetahuan tradisional yang bersangkutan, termasuk didalamnya jaminan akan ketersediaan sumber daya hayati yang terkait dengannya. Dalam hubungan ini, Convention on Biological Diversity menjadi sangat relevan untuk diwujudkan oleh Pemerintah Indonesia melalui suatu produk perundang-undangan sui generis. Bukan itu saja, jaminan ni juga menjadi salah satu amanat dari konstitusi Indonsia bahwa sumber daya alam yang penting bagi orang banyak dikuasi oleh negara untuk sebesar-besarnya kemakmuran rakyat. ${ }^{39}$

\subsection{Hak Kekayaan Intelektual Batik Tradisional Paoman dan Perekonomian Masyarakat Kabupaten Indramayu}

Pada saat sebelum UU No. 19 tahun 2002 tentang Hak Cipta digantikan UU No. 28 Tahun 2014 tentang Hak Cipta, pada regim hak cipta sebagian produk masyarakat yang berkaitan dengan hasil ciptaan masyarakat yang sudah tidak diketahui penciptanya dapat dilindungi melalui Pasal 10 dan Pasal 12 UU No. 19 Tahun 2002, dimana bagi kekayaan intelektual yang bersifat komunal dapat dilakukan pendaftaran, sebagaimana telah dilakukan Pemerintah Kabupaten Indramayu yang telah mendaftarkan 80 motif Batik Paoman, dan telah memperoleh sertifikat pendaftaran hak Cipta berdasarkan pasal 10 ayat (2), Namun setelah diganti dengan UU No. 28 Tahun 2014 tentang Hak Cipta, berkaitan dengan hak cipta batik yang memiliki motif tradisional tidak termasuk ciptaan yang dilindungi.

\footnotetext{
${ }^{39}$ Apa yang tertuang dalam konstutusi tersebut juga merupakan perwujudan dari sistem hukum adat yang menempatkan kepentingan bersama lebih daripada kepentingan pribadi. Oleh karena itu kiranya dapat ditafsirkan bahwa Negara yang menguasai sumber daya alam, termasuk sumber daya hayati, hendaknya lebih berorientasi bahwa pemanfaatan sumber-sumber daya hayati itu adalah untuk sebesar-besarnya kemakmuran rakyat.
} 
Batik Paoman yang memiliki motif tradisional serta telah terdaftar pada Direktorat Jenderal Hak Kekayaan Intelektual RI tahun 2003 tentu tidak diberlakukan UU No. 28 tahun 2014 karena peraturan tidak berlaku surut. Artinya bagi megang haknya serta produsennya dapat memproduksi atau mengekploitasi hasil kekayaan intelektualnya, serta berhak menimati hak moral dan hak ekonominya.

Hasil survey yang dilakukan Penulis pada Departemen Perdagangan dan Perindustrian Kabupaten Indramayu, sejauh ini belum ada yang meminta lisensi atas eksploitasi Batik Tradisional Paoman, sementara ini eksploitasi dilakukan oleh para produsen yang ada di wilayah Indramayu, khususnya di Kelurahan Paoman diman terdapat sentra produksi dan perdagangan batik. Pemerintah Kabupaten Indramayu belum menikmati hak ekonomi, seperti memperoleh pendapatan asli daerah dari hak kekayaan intelektual Batik Tradisional yang dimilikinya. Didalam hal eksploitasi yang dilakukan oleh para produsen batik baik di wilayah, kelurahan Paoman, Desa Penganjang, dan Pabean Ilir, Pemerintah Kabupaten Indramayu tidak menerapkan ketentuan lisensi yang dimilikinya, bahkan Pemerintah Daerah Kabupaten Indramayu melalui Dinas Perdagangan dan Perindustrian membebaskan dan mendorong agar para produsen mengexplor secara optimal terhadap batik-batik tradisonal yang telah dimintakan pendaftaran hak ciptanya, agar memperoleh manfaat ekonomi yang cukup besar.

Dilihat dari aspek perekonomian masyarakat, masyarakat Kelurahan Paoman termasuk salah satu kelurahan yang memperoleh pendapatan yang cukup tinggi dari ekploitasi Batik Tradisonal Paoman atau disebut pula Batik Dermayon. Batik Paoman ini produksinya sebagian besar rumahan, banyak rumah tangga yang memproduksi dan melakukan perdagangan Batik di rumah mereka, serta melakukan pengiriman ke berbagai wilayah, khususnya daerah Jawa barat, Jawa tengah, dan Jawa Timur, sebagian juga ke luar jawa. Tentu dari sisi pendapatan rumah tangga mereka sangat membantu, bahkan termasuk daerah yang sejahtera.

Sementara Pemerintah Daerah tidak mengenakan lisensi terhadap para produsen, yang diperoleh manfaat oleh Pemerintah Daerah Kabupaten Indramayu adalah pajak dari penjualan Batik Tradisional Paoman. Namun dilihat dari pajak yang masuk dari perdagangan Batik paoman masih relative sangat kecil. 


\section{PENUTUP}

\subsection{Simpulan}

Berdasarkan uraian di atas dapat disimpulkan sebagai berikut :

a. Memperhatikan kriteria, karya seni yang dilindungi berdasarkan Pasal 40 ayat (1) huruf j, serta Pasal 38 ayat (1) dan Pasal 39 ayat (1), perlindungan Motif Tradisional Batik Paoman sulit dilakukan melalui regim Hak Kakayaan Intelektual berdasarkan Undang-Undang No. 28 tahun 2014 tentang Hak Cipta.

b. Penetapan UNESCO sebagai salah satu lembaga PBB yang membidangi masalahmasalah kebudayaan Batik sebagai Warisan Kemanusiaan untuk Budaya Lisan dan Nonbendawi (Masterpieces of the Oral and the Intangible Heritage of Humanity) Masyarakat Indonesia, dapat dijadikan sandaran masyarakat Indonesia, termasuk masyarakat Indramayu untuk memperoleh Hak Moral, namun sulit untuk menjadi dasaran tuntutan Hak Ekonomi.

c. Regim sui generis dapat memberikan perlindungan terhadap hak moral maupun hak ekonomi bagi masyarakat pemegang hak kekayaan intelektual masyarakat, termasuk pemegang hak kekayaan intelektual Batik Tradisional Paoman, karena pengaturannya bersifat sederhana, sera dapat memmberikan mafaat dan kesejahteraan, namun model perlindungan ini memerlukan komitmen bersama agar tidak melangar normanorma dan adat istiadat.

\subsection{Saran}

a. Perlu dilakukan perubahan peraturan perundang-undangan tentang Hak Cipta yang secara tegas dapat melindungi Batik Tradisional, termasuk Batik Tradisional Paoman Indramayu, serta mencakup perlindungan hak moral dan hak ekonomi masyarakat, agar tidak terjadinya misappropriation.

b. Perlu adanya mekanisme yang jelas berkaitan dengan tuntutan hak ekonomi pemegang hak kekayaan intelektual, sebagai konsekuensi penetapan UNESCO PBB yang menetapkan Batik sebagai Warisan Dunia non kebendaan dari Indonesia, sehingga memiliki dampak terhadap perekonomian masyarakat. 


\section{DAFAR PUSTAKA}

Abdulkadir Muhammad, Hukum Harta Kekayaan, Citra Adytia Bakti, Bandung, 1994.

Agus Sardjono, Hak Kekayaan Intelektual dan Pengetahuan Tradisional, Alumni, Bandung, 2006.

, Membumikan HKI di Indonesia, Nuansa Aulia, Bandung, 2009.

Ahmad M. Ramli, HAKI : Teori Dasar Perlindungan Rahasia Dagang, Mandar Maju, Bandung, 2000.

Eddy Damian, Hukum Hak Cipta, PT. Alumni, Bandung, 2009.

Hazmuri, Batik Klasik, Jambatan, Jakarta, 1981.

Hilman Hadikusuma, Hukum Perekonomian Adat Indonesia, Citra Aditya Bakti, Bandung, 2001

Kusnaka Adimihardja, "Mendayagunakan Kearifan Tradisi Dalam Pertanian Yang Berwawasan Lingkungan dan Berkelanjutan", dalam Kusanaka Adimihardja dkk, Petani Merajut Tradisi Era Globalisasi, Humaniora Utama Press, Bandung, 1999.

Kusnaka Adimihardja, “Atas Kepemilikan Intelektual : Melindungi Hak Komunal Adat dan Lokal”, Pikiran Rakyat, 5 Mei 2001.

Kusnaka Adimihardja, dkk. Deskripsi Pengetahuan dan Teknologi Lokal Jawa Barat, Laporan Kegiatan Inventarisasi dan Dokumentasi, Kerjasama UPT INRIK UNPAD dengan P2KT PUD-PKM BPP Teknologi, Bandung, 2003

Noegroho Amien Soetiarto, "Hak Atas Kekayaan Intelektual dan Kekayaan Intelektual Tradisional dalam Konteks Otonomi Daerah", dalam Mimbar Hukum, Edisi No. : $34 / \mathrm{II} / 2000$.

Peter Groves, Intellectual Property With Compettion Law and Praktices, Cavendish Publishing Limited, London, 1999.

Rahmaniar Soerianata Djoemena, Ungkapan Sehelai Batik : Its Mystery and Meaning, Djambatan, Jakarta, 1986.

Rebecca Clement, "Misconception of Culture Native Peoples and Cultural Property Under Canadian Law", Toronto Faculty of Law Review (Vo. 49 No. 1, 1991).

R.M. Ismunadar, Tehnik dan Mutu Batik Tradisional Mancanegara, Dahara Prize, Semarang, 1985.

Satjipto Rahardjo, Sisi-Sisi Lain dari Hukum di Indonesia, Buku Kompas, Jakarta, 2003.

Soerjono Soekanto dan Sri Mamuji, Penelitian Hukum Normatif, Grafindo Persada, Jakarta, 1995.

Sunaryati Hartono, Penelitian Hukum di Indonesia Pada Akhir Abad ke-20, Alumni, Bandung, 199. 
Ugrasena Pranidhana, "Hak Cipta Tradisional, Suatau Kajian Hak Cipta Menurut Pandangan Tradisional" dalam Jurnal Penelitian Fakultas Hukum Iniversitas Indonesia Volume 1, No.2, Januari 2000.

Wailah Abu Sudja, Proses Pembuatan dan Pewarnaan Batik di Indonesia, Karya Nusantara, Bandung, 1979.

Yayasan Mitra Budaya Indonesia, Batik Tradisional, Jakarta, 1982.

Yusril Ihza Mahendra, Keynote Speakers in WIPO Asia-Pasific Regional Symposium on Intellectual Property Rights, Traditional Knowledge and Related Issues, Yogyakarta, Indonesia, Oktober 17 to 19,2001 